\title{
Single allele knock-out of Candida albicans CGT1 leads to unexpected resistance to hygromycin B and elevated temperature
}

\author{
Marianne D. De Backer, ${ }^{1}$ Ronald A. de Hoogt, ${ }^{1}$ Guy Froyen, ${ }^{1}$ \\ Frank C. Odds, ${ }^{2}$ Fermin Simons, ${ }^{1}$ Roland Contreras ${ }^{3}$ \\ and Walter H. M. L. Luyten ${ }^{1}$
}

Author for correspondence: Marianne D. De Backer. Tel: +32 146038 81. Fax: +32 14606111. e-mail:mdbacker@janbe.jnj.com

\footnotetext{
1,2 Department of Advanced Bio-Technologies ${ }^{1}$ and Department of Bacteriology and Mycology2, Janssen Research Foundation, Turnhoutseweg 30, B2340 Beerse, Belgium

3 Department of Fundamental and Applied Molecular Biology, University Gent and V.I.B., K.L. Ledeganckstraat 35, B9000 Gent, Belgium
}

\begin{abstract}
Almost all eukaryotic mRNAs are capped at their $\mathbf{5}^{\prime}$-terminus. Capping is crucial for stability, processing, nuclear export and efficient translation of mRNA. We studied the phenotypic effects elicited by depleting a Candida albicans strain of mRNA 5'-guanylyltransferase (mRNA capping enzyme; CGT1). Construction of a Cgt1-deficient mutant was achieved by URA-blaster-mediated genetic disruption of one allele of the CGT1 gene, which was localized on chromosome III. The resulting heterozygous mutant exhibited an aberrant colony morphology resembling the 'irregular wrinkle' phenotype typically obtained from a normal C. albicans strain upon mild UV treatment. Its level of CGT1 mRNA was reduced two- to fivefold compared to the parental strain. Proteome analysis revealed a large number of differentially expressed proteins confirming the expected pleiotropic effect of CGT1 disruption. The disrupted strain was significantly more resistant to hygromycin B, an antibiotic which decreases translational fidelity, and showed increased resistance to heat stress. Proteome analysis revealed a 50-fold overexpression of Ef-1 $1 \mathrm{pp}$ and a more than sevenfold overexpression of the cell-wall heat-shock protein Ssa2p. Compared to a reference strain, the cgt1/CGT1 heterozygote was equally virulent for mice and guinea pigs when tested in an intravenous infection model of disseminated candidiasis.
\end{abstract}

Keywords: Candida albicans, mRNA capping enzyme, CGT1, real-time RNA quantitation, proteome

\section{INTRODUCTION}

The incidence of fungal infections continues to increase, particularly in immunocompromised patients where these infections can be life-threatening. Candida albicans remains the most common pathogen causing deep mycosis in humans (Groll et al., 1998). C. albicans is a commensal, dimorphic fungus with no known sexual cycle. Resistance of fungal pathogens to clinically used antifungal agents used to be a rare occurrence, but has been increasingly documented around the world since the early $1990 \mathrm{~s}$. The increase in infections combined with the reduced efficacy of the currently available drugs lends importance to the discovery of new at-

Abbreviations: GTase, 5' guanylyltransferase; TPase, 5' triphosphatase; DIG, digoxigenin; MALDI, matrix-assisted laser desorption/ ionization; TEF, translation elongation factor. tractive molecular targets for antifungal drugs. A starting point for finding novel molecular targets for such drugs is to study processes that are critical for growth and/or survival of the fungal pathogen. One such process is the acquisition of the $5^{\prime}$ cap, the earliest modification event during eukaryotic mRNA synthesis. The 7-methyl-5'-guanosinetriphosphate- $5^{\prime}-\mathrm{N}$ (m7GpppN) cap was first elucidated in 1975 (Wei \& Moss, 1975; Furuichi et al., 1975; Furuichi \& Miura, 1975). The cap structure has been shown to be essential for protecting mRNA from untimely degradation (Schwer et al., 1998) and to have a positive, though not essential, role in Saccharomyces cerevisiae pre-mRNA splicing (Fresco \& Buratowski, 1996; Schwer \& Shuman, 1996).

The mRNA capping occurs by three sequential enzymic steps in which the $5^{\prime}$ triphosphate terminus of a primary 
transcript is first cleaved to a diphosphate-terminated RNA by mRNA $5^{\prime}$ triphosphatase (TPase; mRNA capping enzyme, $\beta$ subunit), then capped with GMP by mRNA 5' guanylyltransferase (GTase; mRNA capping enzyme, $\alpha$ subunit) and finally methylated at the N7 position of guanine by mRNA cap methyltransferase. Of the three catalytic steps involved in cap formation, the GTase reaction has been studied in most detail (Schwer \& Shuman, 1994, 1996; Schwer et al., 1998; Yamada-Okabe et al., 1998a). As both the GTase and mRNA cap methyltransferase genes are essential in S. cerevisiae (Shibagaki et al., 1992; Mao et al., 1995), it is likely that every step of mRNA capping in S. cerevisiae is essential and that yeasts have no isozymes for enzymes synthesizing the mRNA cap structure (Yamada-Okabe et al., 1996).

Genes encoding GTases have been identified in Can. albicans, Sac. cerevisiae, Schizosaccharomyces pombe, Mus musculus, Homo sapiens and Caenorhabditis elegans. Previous studies have shown that the GMPbinding site of GTase lies within a conserved KXDG motif with the lysine $(\mathrm{K})$ residue being absolutely essential (Schwer \& Shuman, 1994). The hallmark of the RNA capping reaction is the formation of an enzymeguanylate intermediate in which GMP is covalently linked to the lysine residue via a phosphoamide bond. Multiple conserved sequence motifs have now been shown to be essential for the function of mRNA capping enzyme (Shuman et al., 1994; Yamada-Okabe et al., 1998a).

The C. albicans mRNA GTase gene (CGT1) was cloned by functional complementation of a $S$. cerevisiae GTase (ceg1) null mutant and was found to exist as a single copy in the genome of C. albicans strain IFO 1060 (Yamada-Okabe et al., 1996).

Lower and higher eukaryotes clearly differ with respect to the physical linkage of the GTase and TPase functions (Ping Wang et al., 1997). The yeast capping enzymes consist of two subunits (in S. cerevisiae there is a $52 \mathrm{kDa}$ $\alpha$ subunit responsible for GTase activity and $80 \mathrm{kDa} \beta$ subunit responsible for TPase activity), but in higher eukaryotes both GTase and TPase activities are present on a single polypeptide. It has been demonstrated that in higher eukaryotic capping enzymes, the $\mathrm{N}$-terminal part is responsible for TPase activity and the C-terminal part is essential for GTase activity (Yamada-Okabe et al., 1998b).

S. cerevisiae GTase mutants accumulate unspliced mRNA (Fresco \& Buratowski, 1996). Coupling of premRNA splicing to the presence of the cap offers several potential benefits to the cell. First, it provides a mechanism for the splicing machinery to discriminate RNA polymerase II transcripts from those produced by other polymerases. A second benefit is that the splicing machinery will not assemble on partially degraded heterogeneous nuclear RNAs (pre-mRNAs) lacking an m7GpppN cap.

Furthermore, the rate of protein synthesis and the steady-state levels of multiple individual mRNAs are decreased in S. cerevisiae GTase mutants (Fresco \& Buratowski, 1996; Schwer et al., 1998). However, mRNA polyadenylation and nuclear export remain unaffected.

Because of the potential importance of C. albicans CGT1 as an antifungal target we wanted to explore the impact that an inhibitor of CGT1 activity might have on a pathogen and we mimicked this effect by generating a C. albicans strain depleted of CGT1. This was achieved by disrupting one allele of the CGT1 gene in C. albicans strain CAI-4 and subsequent investigation of the resulting phenotypic effects.

\section{METHODS}

Strains and media. C. albicans CAI-4 (ura3::imm434/ ura3::imm434) and its parental strain SC5314 were kindly provided by Dr W. Fonzi, Georgetown University, USA (Fonzi \& Irwin, 1993). C. albicans B2630 was obtained from the American Type Culture Collection (Manassas, VA; no. 44858).

Synthetic selective medium contains $0.67 \%$ yeast nitrogen base without amino acids (Difco), $0 \cdot 2 \%$ Ura dropout powder (Bufferad) and $2 \%$ glucose. Uridine was added at a final concentration of $20 \mu \mathrm{g} \mathrm{ml}^{-1}$ to ensure growth of CAI-4. YPD medium contains $2 \%$ peptone (Difco), $1 \%$ yeast extract (Difco) and 2\% glucose (Sigma).

C. albicans $\mathrm{Ura}^{-}$revertants were selected upon excision of the C. albicans URA3 gene from an integrative transformant strain (see below), on the basis of the resistance of the $\mathrm{Ura}^{-}$ revertants to $5^{\prime}$-fluoroorotic acid (Sigma) and following the procedure of Fonzi \& Irwin (1993).

Construction of CGT1 disruption cassette. A DNA fragment containing the entire coding region of C. albicans CGT1 was obtained from Dr Yamada-Okabe (Nippon Roche Research Center, Japan). The coding region of CGT1 was PCR amplified and cloned into a SmaI-linearized pGEX-2T vector (Smith \& Johnson, 1988) yielding CGT1/pGEX-2T. The coding region of CGT1 was fused in-frame to the GST part of pGEX-2T. The HISG-URA3-HISG cassette was released from pMB7 (a gift from Dr W. Fonzi, Georgetown University, USA; Fonzi \& Irwin, 1993) using BglII/SalI and extended at one end using BglII/SalI linkers. Double-stranded BglII/SalI linkers were obtained through annealing of oligonucleotides A $\left(5^{\prime}\right.$ CCGAATTCTAGAGTCGACA-3') and B (5'-GATCTGTCGACTCTAGAATTCGG-3'). The intermediate construct CGT1/pGEX-2T was cleaved with XhoI to accept the SalIdigested HISG-URA3-HISG cassette. Finally, the plasmid CGT1-URAcassette/pGEX-2T was cleaved with ScaI to release a $6.3 \mathrm{~kb} C G T 1$ disruption cassette (with CGT1 flanking recombinogenic ends of 0.4 and $1 \mathrm{~kb}$ ) to be used for transformation.

Transformation of C. albicans. CAI-4 was transformed by using a modified spheroplast transformation method ( $\mathrm{M}$. Logghe and others, unpublished). Transformants were plated on synthetic selective medium using sterile $0.4 \mathrm{~cm}$ glass pearls (Glaverbel) and incubated for $3-5 \mathrm{~d}$ at $30^{\circ} \mathrm{C}$.

Southern blot analysis. C. albicans strains were grown in $2 \mathrm{ml}$ synthetic selective medium overnight. Genomic DNA was isolated using the Nucleon MI Yeast kit (Amersham) and the concentration of genomic DNA was estimated by analysing a sample on a $0.7 \%$ agarose gel in $0.5 \times \mathrm{TBE}$ and comparison to a known standard molecular mass marker. Approximately 200 ng genomic DNA was digested overnight with XbaI, 
treated with RNase and incubated for $20 \mathrm{~min}$ at $65^{\circ} \mathrm{C}$. Samples were resolved on a $0.7 \%$ agarose gel in $0.5 \times \mathrm{TBE}$ and run for $6 \mathrm{~h}$ at $4 \mathrm{~V} \mathrm{~cm}^{-1}$. DNA was visualized using ethidium bromide staining and subsequent UV transillumination, and blotted onto Hybond-N+ membrane (Amersham) as described by Sambrook et al. (1989). Digoxigenin (DIG)-labelled probes were prepared in a $50 \mu \mathrm{l}$ reaction using DIG-dUTP (Boehringer) at a 1:3 dTTP:DIG-dUTP ratio, $500 \mathrm{pg}$ template plasmid DNA, $1 \times$ PCR buffer II (Perkin Elmer Cetus), $0.4 \mu \mathrm{M}$ each primer (Eurogentec), $0 \cdot 2 \mathrm{mM}$ each dATP, dCTP and dGTP (Perkin Elmer Cetus), $2.5 \mathrm{mM} \mathrm{MgCl}_{2}$ (Perkin Elmer Cetus), and 1.25 U Taq polymerase with TaqStart antibody (Boehringer). A $1.6 \mathrm{~kb}$ URA-blaster-cassette-specific probe fragment was amplified using pMB7 as a template and using primers P3 (5'-CAGCAATTCTCGTGAATCATCG-3') and P5 (5'-TGATCAATTCCTGAGCAACAAC-3'). A $0.5 \mathrm{~kb}$ CGT1-specific probe fragment was amplified using CGT1/pGEX-2T as a template and using primers P6 (5'AGGAATTACGATTGATGGTGGC-3') and P7 (5'-AGGGGAGTTGACTATATCAGG-3'). PCR was performed on denatured $\left(10 \mathrm{~min}\right.$ at $\left.94^{\circ} \mathrm{C}\right) \mathrm{DNA}$ for 30 cycles, each consisting of $1 \mathrm{~min}$ at $94^{\circ} \mathrm{C}, 1 \mathrm{~min}$ at $57^{\circ} \mathrm{C}$ and $2 \mathrm{~min}$ at $72^{\circ} \mathrm{C}$. A final elongation step at $72^{\circ} \mathrm{C}$ for $7 \mathrm{~min}$ completed the reaction.

The membrane was prehybridized at $42{ }^{\circ} \mathrm{C}$ in DIG Easy Hyb (Boehringer) for a minimum of $1 \mathrm{~h}$. Hybridization was performed using $1 \mu \mathrm{l}$ denatured PCR product ( $=1 / 50$ of the total volume) $\mathrm{ml}^{-1}$ DIG Easy Hyb solution. The probes were denatured by heating the PCR reaction for $10 \mathrm{~min}$ at $96{ }^{\circ} \mathrm{C}$, then quick-chilling on ice. The probe was kept on ice for 5 min, centrifuged briefly and diluted in prewarmed DIG Easy Hyb solution. The entire probe solution was filtered through a $0.45 \mu \mathrm{m}$ filter (Millex HV, Millipore) prior to use. Hybridizations were carried out overnight at $42{ }^{\circ} \mathrm{C}$. After hybridization, membranes were washed twice with $2 \times$ SSC, $0 \cdot 1 \%$ SDS at ambient temperature for $15 \mathrm{~min}$ and twice with $0 \cdot 1 \times$ SSC, $0 \cdot 1 \%$ SDS at $68^{\circ} \mathrm{C}$ for $15 \mathrm{~min}$. Detection was performed using the DIG Wash and Block Buffer Set as described by the manufacturer (Boehringer) and the blot was exposed to Kodak XAR-5 film for $1 \mathrm{~h}$ at ambient temperature.

PCR analysis. PCR analyses were used to verify the disruption of the C. albicans CGT1 gene. Primers P1 (5'-TAGAAATTCAGGACCACTATACAC-3') and P2 (5'-CAGAAACCGAGAAAGAATCAAAC-3') were used to distinguish disrupted from wild-type CGT1 genes on the basis of size and are within the CGT1 gene itself. Primers P3 and P4 lie within the URA-blaster disruption cassette. P1 was used in combination with P2 and P3 (5'-CAGCAATTCTCGTGAATCATCG-3'). Primer P2 was used in combination with P4 (5'-CTAACGCAGTCAGGCACCG-3'). PCR was performed on $10 \mathrm{ng}$ denatured $\left(10 \mathrm{~min}\right.$ at $\left.94^{\circ} \mathrm{C}\right)$ genomic DNA using the primer combinations described above (all primers were from Eurogentec) for 30 cycles, each consisting of $1 \mathrm{~min}$ at $94^{\circ} \mathrm{C}, 1 \mathrm{~min}$ at $57^{\circ} \mathrm{C}$ (or $59^{\circ} \mathrm{C}$ for the $\mathrm{P} 1 / \mathrm{P} 2$ primer combination) and $3 \mathrm{~min}$ at $72{ }^{\circ} \mathrm{C}$ (or $6 \mathrm{~min}$ for the $\mathrm{P} 1 / \mathrm{P} 2$ primer combination). A final elongation step at $72{ }^{\circ} \mathrm{C}$ for 7 min completed the reaction. In the reaction mixture $2.5 \mathrm{U}$ Taq polymerase (Boehringer) with TaqStart antibody (Clontech) $(1: 1)$ were used, and the final concentrations were $0 \cdot 2 \mu \mathrm{M}$ each primer, $2 \mathrm{mM} \mathrm{MgCl}$ (Perkin Elmer Cetus) and $200 \mu \mathrm{M}$ dNTPs (Perkin Elmer Cetus). PCR was performed in a Perkin Elmer model 9600 PCR machine.

PFGE. Liquid starter cultures were set up by inoculating each colony into $1 \mathrm{ml}$ synthetic selective medium and incubating overnight at $30{ }^{\circ} \mathrm{C}$ at 300 r.p.m. These cultures were used to inoculate $20 \mathrm{ml}$ synthetic selective medium and incubated overnight at $30^{\circ} \mathrm{C}$ at 300 r.p.m.
Ten mililitres of each culture was centrifuged for $10 \mathrm{~min}$ at $2890 \mathrm{~g}$ and resuspended in filter-sterilized, cold $50 \mathrm{mM}$ EDTA. The cell density was determined using a Coulter Counter (Coulter Z1, Coulter Electronics), a total of $1.4 \times 10^{8}$ cells was transferred to a $1.5 \mathrm{ml}$ Eppendorf tube and centrifuged for $5 \mathrm{~min}$ at $2890 \mathrm{~g}$. The pellet was used to make plugs according to the protocol enclosed with the CHEF genomic DNA plug Kit (Bio-Rad). Electrophoresis of the plugs was performed using a $0 \cdot 8 \%$ agarose (Seakem gold agarose for PFGE, FMC BioProducts) gel in $1 \times$ TAE buffer. As a size marker, Bio-Rad Hansenula wingei chromosomes were used. The Bio-Rad CHEF Mapper II was used for electrophoresis set at the following parameters: switch time, $120 \mathrm{~s}$; final switch time, $480 \mathrm{~s}$; run time, $40 \mathrm{~h}$; voltage, $3 \mathrm{~V} \mathrm{~cm}^{-1}$; angle, $106^{\circ}$. The gel was stained using ethidium bromide at a final concentration of $0.5 \mu \mathrm{g} \mathrm{ml} \mathrm{m}^{-1}$ for $15 \mathrm{~min}$ at ambient temperature and blotted overnight by capillary action (Sambrook et al., 1989) onto a positively charged nylon membrane (Cat. No. 1417240, Boehringer). The $1.6 \mathrm{~kb}$ URA-blaster-cassette-specific probe fragment was amplified as described above and purified using the Qiagen PCR purification kit according to the manufacturer's instructions. Twenty nanograms were labelled with $\left[\alpha^{32} \mathrm{P}\right] \mathrm{dCTP}$ using the Rediprime II labelling system (Amersham Pharmacia Biotech). The chromosomal blot was hybridized and washed as described by Sambrook et al. (1989). The blot was exposed to a Kodak Biomax MS film at $-70{ }^{\circ} \mathrm{C}$ for $1.5 \mathrm{~h}$ with two intensifying screens and developed using the Kodak X-OMAT M43 processor.

Growth monitoring. For liquid cultures, starter cultures were set up by inoculating each colony in $1 \mathrm{ml}$ synthetic selective medium and incubating overnight at $30{ }^{\circ} \mathrm{C}$ at 300 r.p.m. Cell densities were determined using a Coulter counter (Coulter Z1; Coulter Electronics). Subsequently, $2.5 \times 10^{5}$ cells were inoculated into synthetic selective medium in a final volume of $1 \mathrm{ml}$ and cultures were incubated for $24 \mathrm{~h}$ at $30^{\circ} \mathrm{C}$ at 300 r.p.m. Cultures were washed in minimal medium without glucose (S medium) and the pellet was resuspended in $650 \mu \mathrm{l} \mathrm{S}$ medium. Eight microlitres of this culture was used for inoculating $400 \mu \mathrm{l}$ cultures in a Honeywell-100 plate (Bioscreen Analyzer; Labsystems). Each strain was grown at $30^{\circ} \mathrm{C}$ for $48 \mathrm{~h}$ in synthetic selective medium; shaking was at high intensity and was carried out every $3 \mathrm{~min}$ for $20 \mathrm{~s}$. Optical densities were measured every hour. Growth curves were generated automatically using the BioLINK software (Labsystems).

For plate cultures, strains were streaked out on synthetic selective medium/agar plates using an inoculating loop and incubated for $2-3 \mathrm{~d}$ at $30^{\circ} \mathrm{C}$ in a static incubator (Memmert).

Spot test. Starter cultures were set up from each strain and grown to a final density of $2 \times 10^{7}$ cells $\mathrm{ml}^{-1}\left(\mathrm{OD}_{600}=1 \cdot 0\right)$. Cells were plated by transferring $5 \mu \mathrm{l}$ of the original suspension as well as $10^{-1}, 5 \times 10^{-1}, 10^{-2}, 5 \times 10^{-2}, 10^{-3}, 5 \times 10^{-3}, 10^{-4}$, $5 \times 10^{-4}, 10^{-5}$ and $5 \times 10^{-5}$ dilutions onto plates of synthetic selective medium. Spotting was in duplicate and one series was incubated at $30^{\circ} \mathrm{C}$ and the other series at $37^{\circ} \mathrm{C}$ for $3 \mathrm{~d}$. Plates used were synthetic selective medium, synthetic selective medium $+400 \mu \mathrm{g}$ hygromycin $\mathrm{B} \mathrm{ml}^{-1}$ (Sigma), synthetic selective medium $+0.08 \mathrm{M}$ hydroxyurea (Serva), synthetic selective medium without glucose $+2 \%$ galactose, synthetic selective medium without glucose $+2 \%$ galactose $+400 \mu$ g hygromycin $\mathrm{B} \mathrm{ml} \mathrm{m}^{-1}$ and synthetic selective medium without glucose $+2 \%$ galactose +0.08 M hydroxyurea.

Real-time quantitation of the CGT1 mRNA transcript. PCR quantitations using specific primers and probes were performed according to the TaqMan procedure (Livak et al., 
1995; Orlando et al., 1998) using the ABI Prism 7700 sequence detector (Applied Biosystems). Primers and probes for $C$. albicans ACT1, encoding $\beta$-actin, and CGT1 genes were designed using the PrimerExpress software system (Perkin Elmer Cetus). Cells were grown to $\mathrm{OD}_{600} \sim 1 \cdot 0$ and total RNA was prepared using the RNeasy midi kit (Qiagen; mechanical disruption protocol) according to the manufacturer's instructions. All RNA samples were DNaseI (Boehringer, RNase-free)-treated at $20 \mathrm{U} \mathrm{\mu g}^{-1}$ in $50 \mu$ l solution for $40 \mathrm{~min}$ at ambient temperature, phenol/chloroform extracted and precipitated. Pellets were dissolved in $20 \mu \mathrm{l} \mathrm{MilliQ}$ water (Millipore) and RNA concentrations were determined spectrophotometrically by measuring $\mathrm{OD}_{260}$ in a UV-1601 $\mathrm{UV} /$ visible spectrophotometer (Shimadzu). First-strand cDNA synthesis was performed in a final volume of $20 \mu \mathrm{l}$ containing $1 \times$ Superscript RT buffer (Life Technologies), $10 \mathrm{mM}$ DTT, $125 \mu \mathrm{M}$ each dNTP, $50 \mu \mathrm{M}$ hexamer primers (Life Technologies) and $1 \mu \mathrm{g}$ RNA. Mixtures were incubated for $10 \mathrm{~min}$ at ambient temperature and $1 \mu \mathrm{l}$ was removed and diluted 1:4 for the non-amplification control;20 U Superscript reverse transcriptase (Life Technologies) was added and the reaction was incubated for $1 \mathrm{~h}$ at $42{ }^{\circ} \mathrm{C}$. The enzyme was inactivated for $10 \mathrm{~min}$ at $70^{\circ} \mathrm{C}$.

PCR reactions were set up in triplicate for all genes and contained $5 \mu \mathrm{l}$ PCR buffer $\mathrm{A}, 4 \mathrm{mM} \mathrm{MgCl}_{2}, 200 \mu \mathrm{M}$ each dATP, dGTP, dCTP and $400 \mu \mathrm{M}$ dUTP, $250 \mathrm{nM}$ fluorogenic probe (for CGT1: 5'-CTGAATGTCGCCAATCTACAACTAAGAAGGGA-3') labelled at the $5^{\prime}$ end with 6-carboxyfluorescein and at the $3^{\prime}$ end with 6-carboxytetramethylrhodamine (Genset), 1.25 U AmpliTaq Gold, $16.75 \mu \mathrm{H}_{2} \mathrm{O}$, $300 \mathrm{nM}$ of appropriate FORWARD (for CGT1: 5'-AGCAACCATTACAAGGCAGGA-3') and REVERSE (for CGT1: 5'-CTGAATCGAAGCATTTCCCAA-3') PCR primers, $1 \mu \mathrm{l}$ of the reverse transcription reaction mixture. For the nonamplification control, $1 \mu \mathrm{l}$ of the $1: 4$ diluted RTase-negative sample was added while $1 \mu \mathrm{l}_{2} \mathrm{O}$ was added to each nontemplate control sample. The ABI PRISM 7700 was run for 50 cycles of $15 \mathrm{~s}$ at $95^{\circ} \mathrm{C}, 1 \mathrm{~min}$ at $60^{\circ} \mathrm{C}$. These cycles were preceded by $10 \mathrm{~min}$ at $95^{\circ} \mathrm{C}$. Data were analysed using the ABI PRISM 7700 software package. Data were normalized according to ACT1 CT (threshold cycles) values (User bulletin 2, PE Applied Biosystems).

Experimental disseminated C. albicans infections. C. albicans SC5314, B2630 and dCGT1 were maintained on Sabouraud glucose agar (Oxoid). For the preparation of inocula, a yeast colony was lightly touched with a wet inoculating loop and the material on the loop was transferred to $5 \mathrm{ml}$ Sabouraud broth (Oxoid) in a sterile $15 \mathrm{~mm}$ glass test tube. The test tube cultures were rotated at 20 r.p.m. and an angle of $5^{\circ}$ to the horizontal for $18-20 \mathrm{~h}$ at $30 \pm 1{ }^{\circ} \mathrm{C}$ (Odds, 1991). The cell concentration was estimated by means of haemocytometer counts and appropriate dilutions were made in physiological saline for intravenous injection in mice and guinea pigs. Specific pathogen-free albino guinea pigs and NMRI mice were purchased from Charles River. Guinea pigs were housed individually and mice in groups of up to ten animals. They were fed food and water ad libitum. Individual animals were weighed and infected intravenously with C. albicans via either the lateral tail vein (mice) or the lateral vein of the penis (guinea pig). Different test inocula were administered in separate experiments. In the first experiment, the animals were challenged with $10^{4} \mathrm{C}$. albicans cells per g body weight. This dose usually leads to a mean survival time of 5-7 d when the infecting strain is a fresh clinical isolate. On the basis of the survival times at this level of challenge, higher or lower infecting doses were used in subsequent experiments to establish a dose-survival relationship for each of the three $C$. albicans strains.

The animals were observed daily for $21 \mathrm{~d}$. Animals surviving at this time were humanely killed. At a post-mortem examination, the right kidney of each animal was homogenized in $15 \mathrm{ml}$ physiological saline and 10-fold dilutions of the homogenate were plated on Sabouraud agar to determine the organ burden of C. albicans ( $\log _{10}$ c.f.u. per kidney for mice, $\log _{10}$ c.f.u. per gram kidney weight for guinea pigs). Mean survival times, percentage of survivors on day 21, percentage of culturenegative kidneys and mean organ burden for culture-positive kidneys were the parameters used to determine the relative virulence of the infecting strains.

Proteome analysis. The proteomics strategy included highresolution two-dimensional gel electrophoresis, in-gel trypsin digestion followed by identification of a limited set of differentially expressed proteins using different approaches including narrow-bore HPLC followed by N-terminal sequencing, MALDI (matrix-assisted laser desorption/ ionization)-MS or nanospray-MS/MS.

C. albicans starter cultures were set up by inoculating each colony in $1 \mathrm{ml}$ synthetic selective medium and incubating overnight at $30{ }^{\circ} \mathrm{C}$ and 300 r.p.m. Cell densities were determined using a Coulter counter (Coulter Z1; Coulter Electronics). Approximately $2.5 \times 10^{5}$ cells in $1 \mathrm{ml}$ were inoculated in $200 \mathrm{ml}$ synthetic selective medium and cultures were incubated at $30^{\circ} \mathrm{C}$ and 300 r.p.m until a final $\mathrm{OD}_{600}$ of $1 \cdot 0$ was reached.

Cultures were centrifuged for $10 \mathrm{~min}$ at $1470 \mathrm{~g}$ and the supernatant was discarded. The cell pellets were frozen immediately at $-70^{\circ} \mathrm{C}$. The following steps were performed at the Wittmann Institute of Technology and Analysis of Biomolecules (WITA, Germany). Each pellet was crushed in a mortar under liquid nitrogen. The crude extract was dissolved in $588 \mu \mathrm{l} \mathrm{AP}$ buffer (9 M urea, $70 \mathrm{mM}$ DTT, ampholyte mix) and $10 \mu \mathrm{l}$ protease inhibitor mix. The protein extracts were concentrated four-fold prior to application onto the gels. Proteins were separated by a large gel high-resolution twodimensional electrophoresis technique (Klose \& Kobalz, 1995; Brockstedt et al., 1998). All equipment and ready-to-gel solutions were from WITA. Gels were silver stained as described by Heukeshoven \& Dernick (1985). For the identification of individual proteins, preparative high-resolution two-dimensional gels were run and stained with Coomassie blue (Klose \& Kobalz, 1995; Eckerskorn et al., 1988) and the relevant protein spots were excised from the gel manually. Ingel digestion, extraction of the peptides from the crushed acrylamide gel fragment, desalting and concentration by a reversed-phase technique were perfomed according to Otto $e t$ al. (1996). MALDI-MS was performed with a VG Tof Spec (Fisons) equipped with a nitrogen laser and a VAX 400 VLC station using OPUS software, version 3.1. Spectra were obtained in the linear mode by summing 20-50 laser shots. A saturated solution of $\alpha$-cyano-4-hydroxycinnamic acid in aqueous $50 \%(\mathrm{v} / \mathrm{v})$ acetonitrile and $0.1 \%$ liquid trifluoroacetic acid was used as the matrix. The matrix $(1 \cdot 2 \mu \mathrm{l})$ and sample $(0 \cdot 8 \mu \mathrm{l})$ were mixed on the target and air-dried. For mass determination, the dried target was inserted into the mass spectrometer; measurements were under vacuum at 22 and $24 \mathrm{kV}$.

Peptide mixtures were separated on a narrow-bore reversephase HPLC column (Smart-HPLC system, Pharmacia) employing gradients made from $0 \cdot 1 \%$ liquid trifluoroacetic acid in water and $85 \%(\mathrm{w} / \mathrm{v})$ acetonitrile $/ 0.08 \%$ liquid trifluoroacetic acid in water. The fractions were dried and used for Edman micro-sequencing (Wittman-Liebold, 1992). The 
dried peptides were dissolved in acetonitrile/water/TFA (50:45:5 by vol.) and applied to pre-washed Biobrene-coated glass fibre filters and run in a sequencer (Applied Biosystems Instruments; Procise 492 and on-line PTH-amino acid analyser).

Mass fingerprinting by MS was performed using a Q-Tof (Micromass). Operation was at $30^{\circ} \mathrm{C}$ with a nitrogen drying gas flow of about $180 \mathrm{l} \mathrm{h}^{-1}$. A potential of $1.4 \mathrm{kV}$ was applied to the nanoflow borosilicate glass capillary. The peptide mixture of each spot, without pre-separation, was desalted and concentrated in a microtip filled with a few RP-C18 beads (Vydag) and eluted from the reverse phase material with acetonitrile/water/trifluoroacetic acid (50:45:5 by vol.) in a $1 \mu \mathrm{l}$ volume. This solution was introduced into a microcapillary and sprayed into the Z-spray ionic source of the nanospray mass spectrometer. The individual peptide masses were recorded in the time-of-flight analyser of the instrument. For nanospray-MS/MS analysis, the peptide ions were fragmented in the collision hexapole of the instrument. The fragments of each peptide were analysed in the time-of-flight analyser of the instrument, yielding partial sequences. An aliquot of $1 \mu \mathrm{l}$, obtained from half to one-fifth of the Coomassie-stained spot sufficed for one mass-fingerprint spectrum and five to six MS/MS experiments were simultaneously recorded, employing a flow rate of $30 \mathrm{nl} \mathrm{min}{ }^{-1}$. A collision energy of 28-35 V (depending on the charge state of the daughter ions) was applied; the gas pressure in the collision cell was regulated to $6 \cdot 0 \times 10^{-5}$ bar. Calibration of the instrument was done with Glu-fibrinopeptide.

Peptide analysis. The peptide masses of the mass fingerprints obtained from each protein were searched in the SWISSPROT database using the FRAGMOD program (E.-Ch. Muller, Berlin), a modified version of the FRAGFIT program (Henzel et al., 1993). Several other search programs as described by Mueller et al. (1999) were used in case identification was not possible using the above-described strategy.

DNA sequencing. Reactions were performed using the ABI Prism BigDye Terminator Cycle Sequencing Ready Reaction Kit according to the instructions of the manufacturer (PE Applied Biosystems) except for the following modifications. The total reaction volume was reduced to $15 \mu \mathrm{l}$ and volumes of individual reagents were changed accordingly. The $6 \mu \mathrm{l}$ Terminator Ready Reaction Mix was replaced by a mixture of $3 \mu \mathrm{l}$ Terminator Ready Reaction Mix $+3 \mu \mathrm{l}$ Half Term (GENPAK). After cycle sequencing, reaction mixtures were purified over Sephadex G50 columns prepared on Multiscreen HV opaque Microtitre plates (Millipore) and dried in a Speedvac. Reaction products were resuspended in $3 \mu$ l loading buffer. Following denaturation for $2 \mathrm{~min}$ at $95^{\circ} \mathrm{C}$, a $1 \mu \mathrm{l}$ sample was applied to a $5 \%(\mathrm{w} / \mathrm{v})$ Long Ranger Gel $(36 \mathrm{~cm}$ well-to-read) prepared from Singel Packs according to the supplier's instructions (FMC BioProducts). Samples were run for $7 \mathrm{~h}$ with run module $2 \mathrm{X}$ on an $\mathrm{ABI} 377 \mathrm{XL}$ DNA sequencer. Data collection version 2.0 and Sequence analysis version 3.0 (for basecalling) software packages were from PE Applied Biosystems.

\section{RESULTS}

\section{Creation of a strain with diminished levels of mRNA capping enzyme}

To generate a strain with low levels of mRNA capping enzyme, a CGT1 single allele knock-out strain was constructed. Genetic disruption of C. albicans genes is particularly difficult since this fungus (unlike $S$. cere- visiae, for example) has no known sexual cycle or haploid form (although individual genes can be haploid or polyploid). To accomplish disruption of the first allele of the CGT1 gene, the URA-blaster system was used (Fonzi \& Irwin, 1993). Disruption of the CGT1 allele was confirmed in the transformants by PCR and Southern blot analysis. A schematic representation of the wild-type and disrupted alleles of CGT1 is shown in Fig. 1(a).

Confirmation of the disruption of one copy of the $C$. albicans CGT1 gene was obtained by PCR using three different primer combinations. PCR amplification from wild-type CAI-4 genomic DNA (not shown) using primer pair P1/P2 yielded a $1.4 \mathrm{~kb}$ fragment, as expected. Primer pairs $\mathrm{P} 1 / \mathrm{P} 3$ and $\mathrm{P} 2 / \mathrm{P} 4$ did not yield any bands. As one primer in each of these pairs is situated within the URA-blaster cassette which is absent in nontransformed CAI-4 strain, this absence of PCR product is as expected.

PCR amplification from cgt1/CGT1 heterozygote CAI4 genomic DNA using primer pair P1/P2 yielded the expected fragment of $1.4 \mathrm{~kb}$ (Fig. 1b); the second expected fragment of $5.5 \mathrm{~kb}$ from the allele disrupted with the URA-blaster cassette was not observed presumably because of the large size of the fragment and the preferential amplification of the smaller $1.4 \mathrm{~kb}$ fragment. A PCR fragment of $0.5 \mathrm{~kb}$ was obtained with primer pair P1/P3, while primer pair P2/P4 yielded a PCR fragment of $2.6 \mathrm{~kb}$ (Fig. 1b), both as expected.

The correct integration of the URA-blaster cassette into the CGT1 locus was also confirmed by Southern blot analysis. In Southern blots of genomic DNA hybridized with a URA3-specific probe, no signal was detected in the wild-type while 1.5 and $>3.7 \mathrm{~kb} \mathrm{XbaI}$ fragments corresponding to the disrupted allele were detected in the cgt1/CGT1 heterozygote (Fig. 1c). In identical blots hybridized with a CGT1-specific probe, a $2 \mathrm{~kb} X b a \mathrm{I}$ fragment representing the wild-type allele and $0.5 \mathrm{~kb}$ and $>3.7 \mathrm{~kb}$ fragments corresponding to the disrupted allele were found in the cgt1/CGT1 heterozygote (Fig. 1c).

Attempts were made to construct a homozygous cgt1/cgt1 null mutant. The URA3 marker in the cgt1/CGT1 heterozygote was removed by growth on $5^{\prime}$ fluoroorotic acid and loss of this marker was checked by Southern hybridization (data not shown). One $\mathrm{Ura}^{-}$ revertant was selected for transformation using the disruption cassette previously used for the generation of the single allele knock-out. A total of 13 transformants were checked by Southern blot analysis for homozygous disruption of the CGT1 gene (data not shown). Homozygous null strains were not recovered (8 integration events occurred at the already disrupted allele; 5 integrations occurred outside of the CGT1 locus).

\section{Chromosomal localization of CGT1}

The location of the CGT1 gene was assigned by separating the chromosomes of the cgt1/CGT1 heterozygote by PFGE (Gerring et al., 1991; Magee, 1994a, 
(a) Xbal (1383)

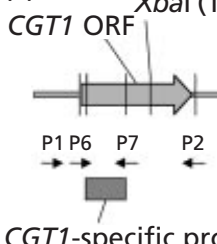

CGT1-specific probe

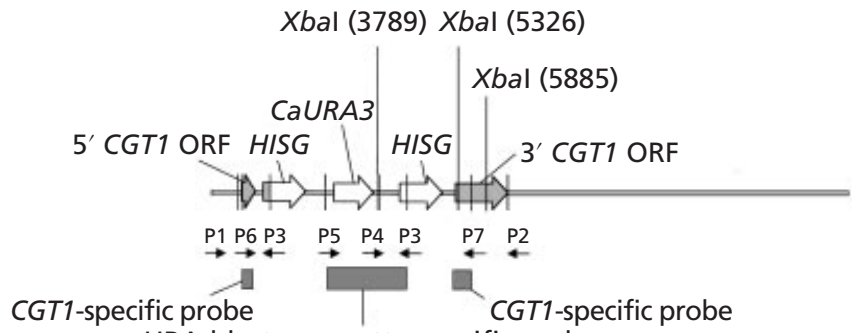

URA-blaster-cassette-specific probe (b)

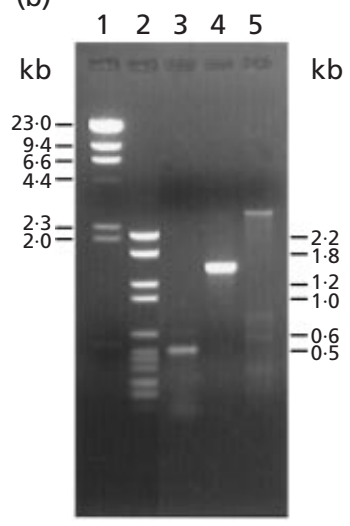

(c)

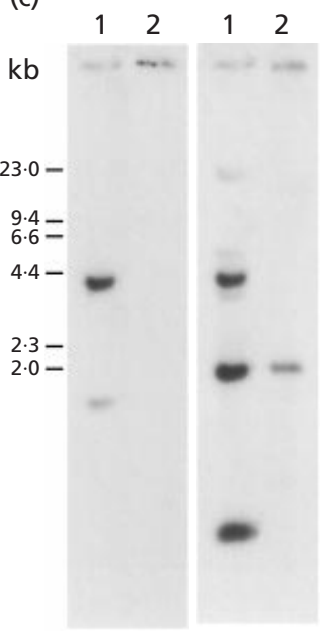

Fig. 1. Targeted disruption of C. albicans CGT1. (a) Genomic arrangement of the CGT1 locus in wild-type strain CAI-4 (top) and cgt1/CGT1 heterozygote (bottom). Locations of the primers (Pn) used for PCR analysis and probes used for Southern blot analysis are indicated on the map. (b) PCR confirmation of the disruption of one copy of the $C$. albicans CGT1 gene. Lane 1, molecular mass marker II (Boehringer); lane 2, molecular mass marker VI (Boehringer); lane 3, PCR amplification with cgt1/CGT1 genomic DNA using primer pair P3/P4; lane 4, PCR amplification with cgt1/CGT1 genomic DNA using primer pair P1/P2; lane 5, PCR amplification on cgt1/CGT1 genomic DNA using primer pairs P2/P5. (c) Confirmation of the disruption of one copy of the C. albicans CGT1 gene by Southern blot analysis. Lane 1, genomic DNA from cgt1/CGT1 heterozygote cleaved with Xbal; lane 2, genomic DNA from the parental CAl-4 strain cut with Xbal. The probe in the left panel was a $1.6 \mathrm{~kb}$ fragment of the URA-blaster cassette and in the right panel was a $0.5 \mathrm{~kb}$ CGT1specific gene fragment.

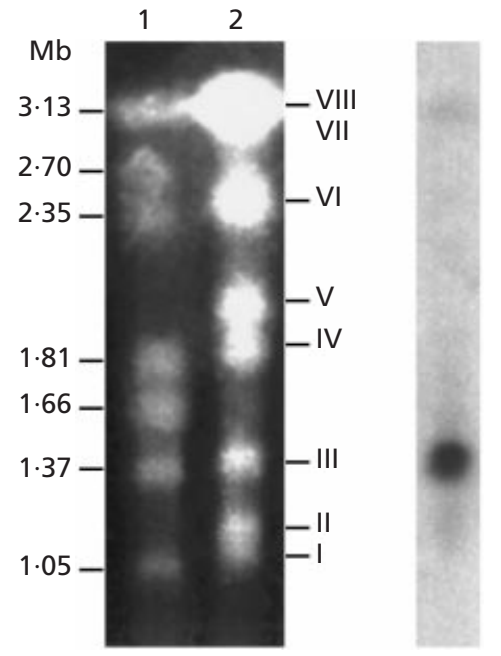

Fig. 2. Localization of the disrupted C. albicans CGT1 gene to chromosome III. Left panel: lane 1, Hansenula wingei chromosomes (Bio-Rad); lane 2, C. albicans cgt1/CGT1 heterozygote chromosomes. Right panel: Southern blot analysis showing hybridization of the CGT1-URA3-specific probe to chromosome III.

b) followed by blotting and hybridization to a CGT1/URA3-specific probe. The CGT1 gene was localized to chromosome III (Fig. 2; chromosome numbering is as described by Rustchenko-Bulgac et al., 1990). Comparing the electrophoretic karyotypes of the
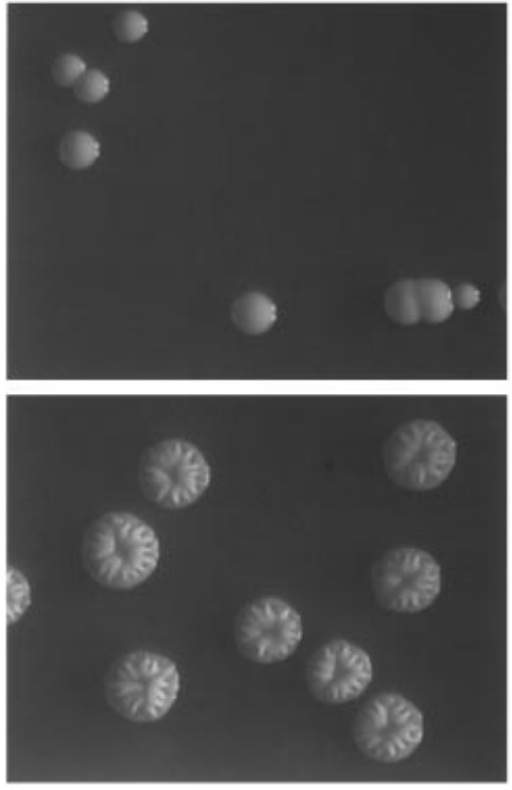

Fig. 3. Colony morphology of the cgt1/CGT1 heterozygote (bottom) and the parental strain (top). Plates were incubated for an equal length of time.

parental strain and a cgt1/CGT1 heterozygote (disruption confirmed by both PCR and Southern blot analysis) did not reveal any obvious genetic aberrations (data not shown). 
(a)

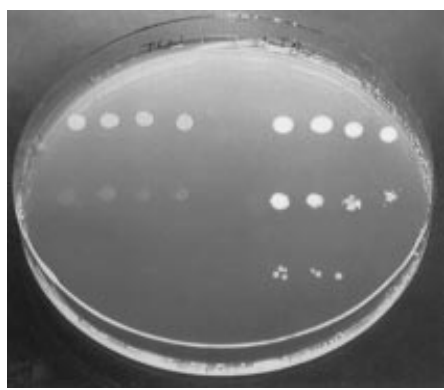

(b)

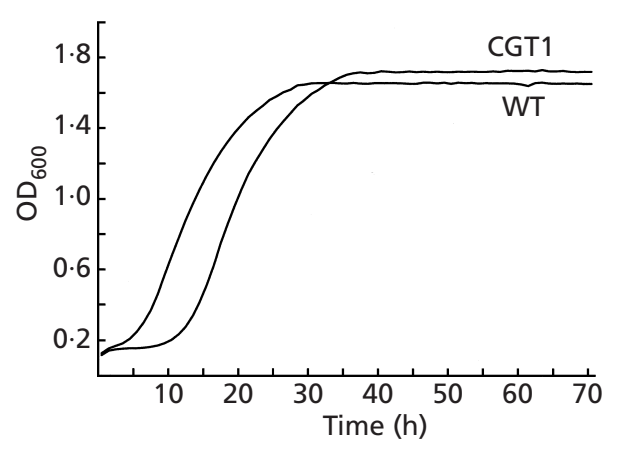

(c)

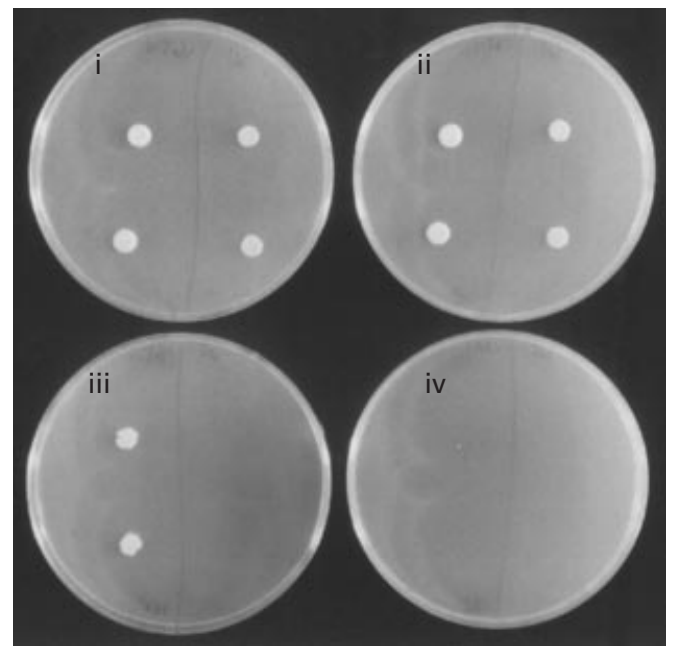

Fig. 4. (a) Spot test: two-fold dilutions of an inoculum of each strain were spotted onto the plate. cgt1/CGT1 heterozygote (right) and parental strain (left) were tested for growth in the presence of hygromycin B (400 $\left.\mu \mathrm{g} \mathrm{ml} \mathrm{m}^{-1}\right)$. (b) Growth curve of the cgt1/CGT1 heterozygote and its parental strain with optical densities measured every hour over $70 \mathrm{~h}$ while incubating at $30^{\circ} \mathrm{C}$ in a Bioscreen Analyzer (Labsystems). (c) Growth after heat shock at $55{ }^{\circ} \mathrm{C}$ of 0 (i), 90 (ii), 120 (iii) or 180 (iv) $\mathrm{min}$ and subsequent incubation at $30^{\circ} \mathrm{C}$ for a total incubation time of $48 \mathrm{~h}$ of the cgt1/CGT1 heterozygote (left; duplicate spots) and the parental strain (right; duplicate spots).
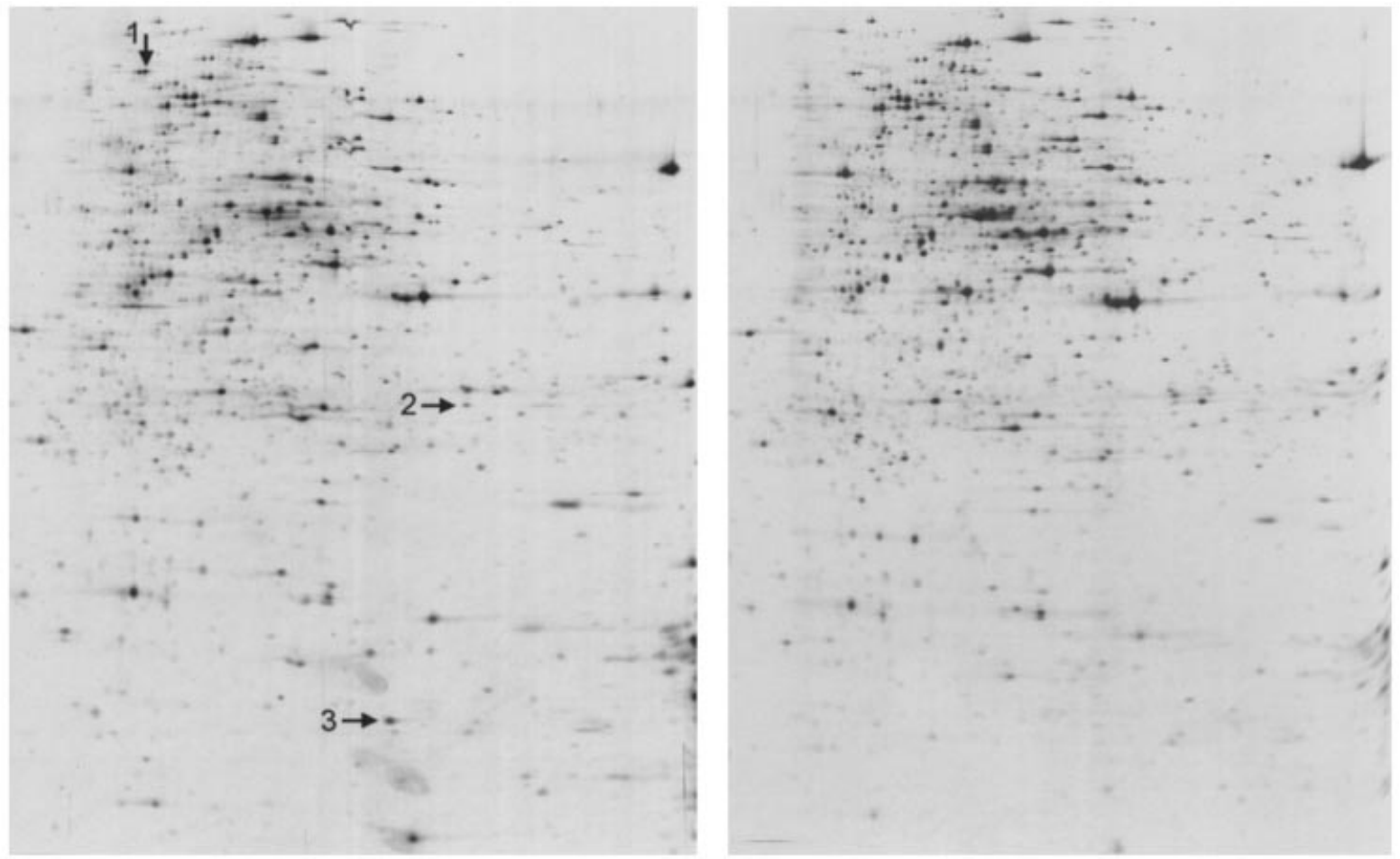

Fig. 5. Two-dimensional gel electrophoresis of whole protein extracts from the cgt1/CGT1 heterozygote (left) and its parent strain CAI-4 (right). Spots of three proteins upregulated in the cgt1/CGT1 heterozygote and identified by MS are marked by arrows $(1=$ Ssa2p, $2=\operatorname{Rps} 5 p, 3=E f 1 \alpha p)$. 

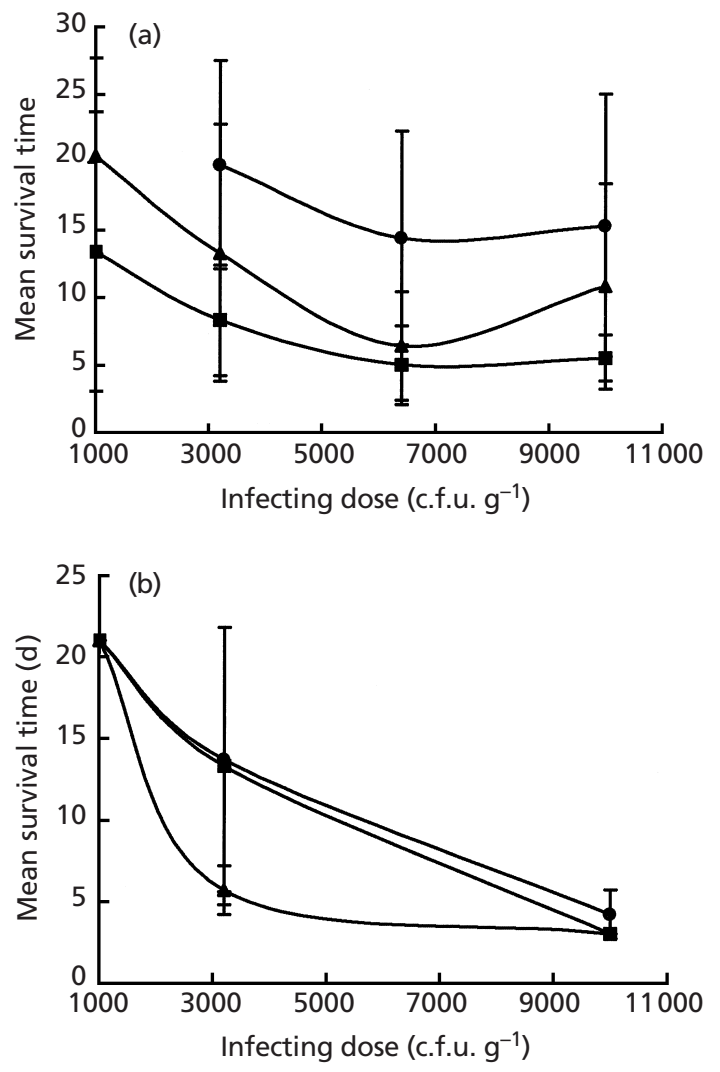

Fig. 6. Mean survival times $\pm S D$ for mice (a) and guinea pigs (b) infected intravenously with C. albicans B2630 (0), SC5314(ש) and dCGT1( $\mathbf{\Delta})$ (cgt1/CGT1 heterozygote).

\section{Real-time quantitation of the CGT1 mRNA transcript}

To determine whether disruption of one CGT1 allele leads to reduced levels of CGT1 transcript, we performed a real-time mRNA quantitation by PCR. Real-time quantitative PCR measures PCR product accumulation with a fluorogenic probe and allows accurate quantitation of transcripts (Heid et al., 1996; Lie \& Petropoulos, 1998). Four independent quantitation experiments were performed using two independently isolated RNA samples from the parental CAI-4 strain and the cgt1/CGT1 heterozygote. Relative CGT1 mRNA levels were determined using the comparative $\mathrm{C}_{\mathrm{T}}$ method (user bulletin 2, PE Applied Biosystems) in which $\beta$-actin mRNA levels are used to normalize the data and differences are expressed in relation to the wild-type controls. Three independent quantitation experiments using identical RNA preparations showed $4 \cdot 8$-, 3.8- and 2.6-fold less CGT1 transcript in the cgt1/CGT1 heterozygote than in the parental CAI-4 strain. A fourth quantitation experiment using an independently isolated RNA preparation showed 2-fold less CGT1 transcript in the cgt1/CGT1 heterozygote than in the parental CAI-4 strain. These results demonstrated a clear reduction in the expression of the CGT1 mRNA in the heterozygote, although to a varying extent (2-5-fold).

\section{Colony morphology}

A very striking difference in colony morphology and size was observed between the parental CAI-4 strain and the cgt1/CGT1 heterozygote when grown on minimal medium with glucose as a carbon source. While the parental strain produced perfectly circular, smooth colonies, the cgt1/CGT1 heterozygote produced much larger, irregularly shaped, colonies with a tentacle-like structure growing from the inside of the colony, resembling the so-called 'irregular wrinkle' phenotype (Fig. 3). A second, independently derived cgt/CGT1 heterozygote displayed an identical phenotype.

Microscopic examination of samples cut from the lower smooth part of the colony and the upper tentacle-like structure showed ellipsoidal blastoconidial ('yeast-like') and true hyphal ('hyphal-like') growth, respectively (data not shown).

\section{Growth analysis}

The parental CAI-4 and the cgt1/CGT1 heterozygote strains were grown at $30{ }^{\circ} \mathrm{C}$ for $70 \mathrm{~h}$ in synthetic selective medium. Optical densities were measured every hour and growth curves were generated (Bioscreen analyser; Labsystems). These demonstrate that the cgt1/CGT1 heterozygote strain had a somewhat longer lag phase compared to the parental strain (Fig. 4b) but it eventually reaches slightly higher optical densities at stationary phase.

\section{Drug susceptibility and temperature sensitivity}

One way to address the possible role of a potential drug target is to observe the phenotypes elicited by genetic or pharmacological interference with that target (Giaever et al., 1999). However, to date no compounds have been reported to act specifically on the mRNA capping enzyme. One might expect pleiotropic effects upon decreases in Cgt1p levels due to the universal role of Cgt1p in the synthesis of all mRNAs. We therefore tested the parental CAI-4 and the cgt1/CGT1 heterozygote strains for possible differences in susceptibility to hygromycin B (an antibiotic which decreases translational fidelity) and hydroxyurea (a ribonucleotide reductase inhibitor). Surprisingly, the cgt1/CGT1 heterozygote strain was clearly more resistant to hygromycin B (Fig. 4a). No difference was found in susceptibility to hydroxyurea. Both strains grew equally well on medium containing galactose as the carbon source (data not shown). Growth at $42{ }^{\circ} \mathrm{C}$, however, unexpectedly revealed an increased resistance of the cgt1/CGT1 heterozygote to elevated temperature (data not shown). Resistance to heat stress was therefore further examined by studying the effects of heat-shock treatments at $55^{\circ} \mathrm{C}$. Inocula of $10^{5}$ exponentially growing cells $\mathrm{ml}^{-1}$ were spotted onto YPD agar to be challenged at $55^{\circ} \mathrm{C}$ for periods of 0 to $180 \mathrm{~min}$ and further incubated at $30{ }^{\circ} \mathrm{C}$ for a total incubation time of $48 \mathrm{~h}$. The results (Fig. 4c) show that cgt1/CGT1 
Table 1. Virulence testing of cgt1/CGT1 heterozygote

ND, not done.

\begin{tabular}{|c|c|c|c|c|c|c|c|c|}
\hline \multirow[t]{2}{*}{ Strain } & \multirow{2}{*}{$\begin{array}{c}\text { Dose } \\
\left.\text { (c.f.u. } \mathrm{g}^{-1}\right)\end{array}$} & \multirow{2}{*}{$\begin{array}{c}\text { No. } \\
\text { animals }\end{array}$} & \multicolumn{2}{|c|}{ Survival $(\mathrm{d}) *$} & \multirow{2}{*}{$\begin{array}{c}\text { Survival } \\
(\%)^{*}\end{array}$} & \multirow{2}{*}{$\begin{array}{c}\text { Negative } \\
\text { kidneys } \\
(\%)\end{array}$} & \multicolumn{2}{|c|}{ Organ burden } \\
\hline & & & Mean & SD & & & Mean & SD \\
\hline \multicolumn{9}{|c|}{ Mouse experiments } \\
\hline \multirow[t]{3}{*}{ B2630 } & 3200 & 10 & $19 \cdot 8$ & $7 \cdot 7$ & 30 & 0 & $7 \cdot 3$ & $0 \cdot 3$ \\
\hline & 6400 & 10 & $14 \cdot 4$ & $7 \cdot 9$ & 0 & 0 & $7 \cdot 2$ & $0 \cdot 4$ \\
\hline & 10000 & 10 & $15 \cdot 3$ & $9 \cdot 7$ & 20 & 0 & $7 \cdot 0$ & $0 \cdot 6$ \\
\hline \multirow[t]{4}{*}{ SC5314 } & 1000 & 10 & $13 \cdot 4$ & $10 \cdot 3$ & 30 & 0 & $6 \cdot 2$ & $1 \cdot 1$ \\
\hline & 3200 & 10 & $8 \cdot 3$ & $4 \cdot 1$ & 0 & 0 & $6 \cdot 3$ & $0 \cdot 4$ \\
\hline & 6400 & 10 & $5 \cdot 0$ & $2 \cdot 9$ & 0 & 0 & $6 \cdot 5$ & $0 \cdot 6$ \\
\hline & 10000 & 10 & $5 \cdot 5$ & $1 \cdot 7$ & 0 & 0 & $6 \cdot 1$ & $0 \cdot 6$ \\
\hline \multirow[t]{4}{*}{ dCGT1 } & 1000 & 10 & $20 \cdot 5$ & $7 \cdot 2$ & 30 & 0 & $6 \cdot 6$ & $0 \cdot 5$ \\
\hline & 3200 & 10 & $13 \cdot 3$ & $9 \cdot 5$ & 10 & 0 & $6 \cdot 6$ & $0 \cdot 4$ \\
\hline & 6400 & 10 & $6 \cdot 4$ & $4 \cdot 0$ & 0 & 0 & $6 \cdot 3$ & $0 \cdot 6$ \\
\hline & 10000 & 10 & $10 \cdot 8$ & $7 \cdot 6$ & 0 & 0 & $6 \cdot 1$ & $0 \cdot 6$ \\
\hline \multicolumn{9}{|c|}{ Guinea pig experiments } \\
\hline \multirow[t]{3}{*}{ B2630 } & 1000 & 6 & $21 \cdot 0$ & $0 \cdot 0$ & 100 & 100 & ND & ND \\
\hline & 3200 & 6 & $13 \cdot 7$ & $8 \cdot 1$ & 50 & 0 & $3 \cdot 8$ & $1 \cdot 2$ \\
\hline & 10000 & 6 & $4 \cdot 2$ & 1.5 & 0 & 0 & $5 \cdot 2$ & $0 \cdot 3$ \\
\hline \multirow[t]{3}{*}{ SC5314 } & 1000 & 6 & $21 \cdot 0$ & $0 \cdot 0$ & 100 & 100 & ND & ND \\
\hline & 3200 & 6 & $13 \cdot 3$ & $8 \cdot 5$ & 50 & 50 & $4 \cdot 7$ & $0 \cdot 4$ \\
\hline & 10000 & 6 & $3 \cdot 0$ & $0 \cdot 0$ & 0 & 0 & $5 \cdot 5$ & $0 \cdot 3$ \\
\hline \multirow[t]{3}{*}{ dCGT1 } & 1000 & 6 & $21 \cdot 0$ & $0 \cdot 0$ & 100 & 100 & ND & ND \\
\hline & 3200 & 6 & $5 \cdot 7$ & $1 \cdot 5$ & 0 & 0 & $4 \cdot 6$ & $0 \cdot 5$ \\
\hline & 10000 & 6 & $3 \cdot 0$ & $0 \cdot 0$ & 0 & 0 & $5 \cdot 6$ & $0 \cdot 5$ \\
\hline
\end{tabular}

* Mean survival times \pm SD and percentage of survival in mice (at day 28) and guinea pigs (at day 21) for animals infected intravenously with C. albicans B2630, SC5314 and dCGT1 are shown.

† Organ burdens $\left(\log _{10}\right.$ c.f.u. per kidney for mice, $\log _{10}$ c.f.u. per g kidney weight for guinea pigs) of $C$. albicans in mice and guinea pig kidney after intravenous challenge are given. The organ burden was calculated only for kidneys with detectable C. albicans in culture.

heterozygosity leads to significantly increased thermal resistance.

\section{Two-dimensional gel electrophoresis and analysis}

The universal role of CGT1 in the synthesis of all mRNAs prompted us to compare overall protein expression between the parental CAI-4 and the cgt1/CGT1 heterozygote.

Total protein extracts from parental CAI-4 and cgt1/CGT1 heterozygote strains were separated by high-resolution two-dimensional gel electrophoresis. In general, the wild-type sample yielded a denser pattern and showed more intense staining of the proteins, which suggests that the protein concentration was higher on average in the wild-type than in the mutant (Fig. 5). Although the pattern of protein spots was strikingly similar, a very large number of differentially expressed proteins could be detected (Fig. 5). Approximately 1600 protein spots were identified for the parental strain while the cgt1/CGT1 heterozygote showed almost 1500 spots. As expected, most differentially expressed pro- teins were more abundant in the parental strain; however, a few proteins strikingly more abundant in the mutant were identified. Underexpression in the mutant varied from 1.2- to 77 -fold, with most proteins falling in the 2- to 10-fold range. Seven spots representing proteins overexpressed in the cgt1/CGT1 heterozygote were excised from the gels and subjected to in-gel digestion, extraction of the peptide mixture from the gel, desalting and peptide concentration determination. The total peptide mixture was either used directly for analysis by MALDI- or nanospray-MS, or the mixture was separated by HPLC in order to sequence individual peptide fragments by Edman degradation. These approaches were used in combination to identify the protein and assign some function to it (based on similarities of the sequence to sequences of other proteins with reported function). Three spots were identified unambiguously. Translation elongation factor 1- $\alpha$ (Sundstrom et al., 1990; Dinman \& Kinzy, 1997; Kovalchuke et al., 1998) was found to be overexpressed in the mutant $(\sim 50$ fold) as were a heat-shock protein, Ssa2p ( 7.4-fold; Lopez-Ribot et al., 1996) and a ribosomal protein, Rps5p ( 5·4-fold; Ignatovich et al., 1995) (Fig. 5). 


\section{Experimental disseminated C. albicans infections in mice and guinea pigs}

Three strains of C. albicans, SC5314, B2630 and the CGT1 single allele knock-out (dCGT1), were injected intravenously at different concentrations into guinea pigs or mice (Fig. 6). In mice, SC5314 showed statistically $(t$-test, $p<0 \cdot 05)$ higher lethality than B2630 (lower mean survival time for a given inoculum size). B2630 and dCGT1 were equally lethal. In guinea pigs, no difference in lethality was observed between the three strains (Table 1). The organ burden of C. albicans $\left(\log _{10}\right.$ c.f.u. per kidney for mice, $\log _{10}$ c.f.u. per g kidney weight for guinea pigs) was comparable for all administered infective doses in one animal type (Table 1).

\section{DISCUSSION}

In our search for novel molecular targets for antifungal drugs we chose to study processes that are critical for growth and/or survival of the fungal pathogen. One such process is the acquisition of the $5^{\prime}$ cap during mRNA synthesis, with GTase (CGT1) as one of the key enzymes. To get an idea of the impact that an inhibitor of CGT1 activity might have on a pathogen, we mimicked this effect by generating a C. albicans derivative that expressed reduced levels of Cgt1p.

To achieve this we disrupted one allele of the CGT1 gene in C. albicans strain CAI-4 by integrative transformation with a URA-blaster cassette containing CGT1 flanking recombinogenic ends. Correct and unique integration of the disruption cassette was confirmed by PCR and Southern blot analysis. Attempts to generate a homozygous cgt1/cgt1 null strain failed, indicating that CGT1 is probably essential for growth of the organism. This was previously shown to be the case in $S$. cerevisiae (Shibagaki et al., 1992). The disrupted gene was localized to chromosome III and the disruption did not induce any obvious chromosomal aberrations.

As expected, we found a clear reduction in CGT1 mRNA in the cgt1/CGT1 heterozygote compared to the parental strain. Although a $50 \%$ reduction in CGT1 transcript might be expected when knocking out one allele of a gene from a diploid organism, we found more pronounced effects, with a reduction of CGT1 transcript level to up to $80 \%$. This might indicate either that the second intact allele is transcribed less or that both copies work together to achieve efficient transcription. This also shows that C. albicans can survive with lower than wild-type levels of CGT1 mRNA.

It has been demonstrated that C. albicans is highly adaptive, suggesting it can rapidly modify its own physiology and phenotype in response to altered conditions. The pleiotropic effects that can be expected upon a decrease in CGT1 activity might thus explain the aberrant phenotype of the cgt1/CGT1 heterozygote strain. Although we did not introduce the wild-type CGT1 allele back into the heterozygote derivative to show restoration of the phenotype, we could demonstrate that independently derived heterozygotes ex- hibited the same aberrant phenotype. The 'irregular wrinkle' phenotype exhibits both yeast-like and true hyphal growth in one colony. There was no evidence of switching in subcultures of the cgt1/CGT1 heterozygote, implicating a stable phenotype. Radford et al. (1994) reported that wrinkled colonies are composed almost entirely of branched hyphal cells with very few blastospores. Hyphal growth is encouraged by high temperature, a high ratio of $\mathrm{CO}_{2}$ to $\mathrm{O}_{2}$, neutral $\mathrm{pH}$ and nutrient-poor media (Lee et al., 1975; Buffo et al., 1984; Soll, 1986). Conversely, low temperature, aeration, acidic $\mathrm{pH}$ and enriched media promote blastospore growth (Lee et al., 1975; Buffo et al., 1984; Soll, 1986). Each strain of C. albicans, in addition to being capable of differentiating in a reversible fashion into a budding or a hyphal growth form (Soll, 1986) is also capable of undergoing high-frequency switching of colony phenotype. The 'irregular wrinkle' phenotype is one of a limited number of general phenotypes described to occur during this switching process (Slutsky et al., 1985; Soll, 1992; Radford et al., 1994). The frequency of switching is influenced by environmental conditions. Switching is influenced by stress conditions such as heat, UV irradiation and ageing (Slutsky et al., 1985; Rikkerink et al., 1988; Morrow et al., 1989; Soll, 1992) and is controlled by the SIR 2 gene (Pérez-Martin et al., 1999). As C. albicans has no known sexual cycle, the ability to switch phenotype could be an alternative way to obtain the variability required to survive in certain environments. Cells in the middle of cgt1/CGT1 heterozygote colonies are presumably exposed to a different microenvironment from cells in the middle of a wild-type colony or have acquired restricted capabilities to cope with certain environmental stress factors. In the middle of the colony, nutrients are depleted earlier; this could be exacerbated by the reduced mRNA capping activity and subsequent decrease in a number of proteins responsible for the transport or metabolism of nutrients.

The pleiotropic effects that can be expected upon a decrease in Cgt1p activity are expected to lead to all sorts of defects and decreased function. Indeed, the cgt1/CGT1 heterozygote showed a clearly extended lag phase compared to the parental strain, although eventually growth catches up. Apparently this initial backlog in growth does not allow for the immune system of the host (tested here in mice and guinea pigs) to combat the infection more efficiently. Decreased virulence observed in strains constructed using the URA-blaster cassette cannot unambiguously be attributed in all cases to the disrupted gene itself (Lay et al., 1998) because expression of the URA3 (orotidine- $5^{\prime}$-phosphate decarboxylase) gene in the derivatives might affect virulence. For this reason the $\mathrm{Ura}^{+}$parental strain of CAI-4, SC5314, was used for comparison with the cgt1/CGT1 mutant. However, various strains carrying the URA-blaster cassette have been tested for Ura3p activity and showed reduced activities compared to that of the wild-type. As the activity levels vary from strain to strain, positional effects have been suggested (Lay et al., 1998). Altered expression of $U R A 3$ in gene-disrupted C. albicans strains 
might thus complicate the interpretation of results obtained in virulence studies. The cgt1/CGT1 mutant strain and the parental strain (SC5314) were equally virulent for mice and guinea pigs when tested in an intravenous infection model of disseminated candidiasis.

Some observations (Sandbaken et al., 1990; Hinnebusch \& Liebman, 1991) suggest that under- or overexpression of any component of a process (e.g. translation) could lead to altered sensitivity to an inhibitor of a relevant step in that process. Such an inhibitor is expected to be more potent against a cell limited by a deficiency in this component and less potent against a cell containing an excess of that component, compared to the wild-type cell. Following this line of reasoning, we expected the cgt1/CGT1 heterozygote to be more susceptible to certain drugs and tested the parental CAI-4 strain and the cgt1/CGT1 heterozygote for possible differences in susceptibility to hygromycin B and hydroxyurea. Unexpectedly, the cgt1/CGT1 heterozygote was found not to be more, but significantly less, sensitive to hygromycin B. This antibiotic inhibits peptide chain elongation by yeast polysomes by preventing translation elongation factor 2-dependent translocation (Gonzalez et al., 1978). Sensitivity to this drug has been shown to correlate with reduced translational fidelity (Palmer et al., 1979; Singh et al., 1979). Another unexpected finding was the increased resistance of the cgt1/CGT1 heterozygote to high-temperature stress.

To elucidate possible mechanisms behind these observations we looked at the effects of CGT1 depletion on global changes in protein expression by two-dimensional gel electrophoresis and MS coupled with searches of protein and EST databases (Blackstock \& Wier, 1999). The amount of protein loaded on each twodimensional gel was derived from an equal number of Candida cells. The wild-type has a denser pattern and more strongly staining protein spots compared to the cgt1/CGT1 mutant. The pleiotropic effects that one might expect upon Cgt1p depletion are reflected in the large number of differentially expressed proteins. Sequencing of peptides derived from a number of proteins whose level was decreased in the mutant led to the identification of proteins in different pathways (data not shown), confirming pleiotropic effects. Surprisingly, the level of a number of proteins was clearly and significantly increased.

One of these proteins is Rps5p. Little is known about the function of Rps5p in higher eukaryotes but its counterpart in E. coli, S7, has been extensively studied. S7 is crucial for the assembly of the $30 \mathrm{~S}$ ribosomal subunit, it contacts residues in the anticodon stem-loop of ribosome-bound tRNAs and it is the primary mRNAbinding protein in ribosomes. In S. cerevisiae, RPS5 exists as a single copy, intronless gene and is essential for viability. It is known that production of ribosomal proteins and rRNAs increases and decreases according to requirement (Woolford \& Warner, 1991). As CGT1 has such a vast impact on all RNAs, its depletion might lead to altered expression of ribosomal proteins as a means to enhance efficiency of translation.
A second protein was expressed at a significantly higher level $(\sim 50$-fold $)$ in the disruptant was Ef-1 $\alpha \mathrm{p}$, a translation elongation factor catalysing the critical step of delivering aminoacyl-tRNAs to the ribosome (Sundstrom et al., 1990; Dinman \& Kinzy, 1997; Kovalchuke et al., 1998). This overexpression might explain the significantly reduced sensitivity to hygromycin B. Dinman \& Kinzy (1997) described a series of $S$. cerevisiae strains containing mutant TEF1 alleles showing increased sensitivity to hygromycin B and other compounds affecting translational elongation. The mechanism by which such a vast overexpression of a protein can be explained remains speculative. It could be envisaged that upon Cgt1p depletion, the level of nearly all mRNA transcripts is lowered. If Cgt1p is a repressor protein, genes solely regulated by this protein might become deregulated and thus overexpressed. This is working on the assumption that intact mRNA would be available for processing and that proteins involved in the translational machinery are sufficiently present. The latter could be assumed as eukaryotic ribosomal protein mRNAs have been described to have a long half-life (Simonin et al., 1997; Liu \& Fallon, 1998).

A third protein also clearly up-regulated in the cgt1/CGT1 heterozygote is the cell-wall-associated protein Ssa2p (HS72), a member of the heat-shock HSP70 family. HSP70 family members are highly conserved proteins that contribute to the protection and repair of cells after exposure to stress conditions and they are found in different cellular locations (Ellis \& van der Vies, 1991; Mager \& Ferreira, 1993). Eukaryotic cells subjected to a $42{ }^{\circ} \mathrm{C}$ heat-shock respond by rapidly increasing the synthesis of a set of evolutionarily conserved heat-shock proteins. However, in contrast to the heat-shock proteins Ssa1p, Ssa3p and Ssa4p, which accumulate to high levels in $S$. cerevisiae subjected to high temperature $\left(42{ }^{\circ} \mathrm{C}\right)$, Ssa2 $\mathrm{p}$ was found to be constitutively expressed (Nicolet \& Craig, 1991; Schwer et al., 1998). Heat-shock proteins in C. albicans have been detected throughout the range of $41^{\circ} \mathrm{C}$ to $46^{\circ} \mathrm{C}$ (Zeuthen \& Howard, 1989). The C. albicans heat-shock protein $S s a 2 p$ was demonstrated to be present in the cell wall and was found to be equally expressed by $C$. albicans at both $25^{\circ} \mathrm{C}$ and $37^{\circ} \mathrm{C}$ (Lopez-Ribot et al., 1996). Ssa2p expression studies at elevated temperatures $\left(41^{\circ} \mathrm{C}\right.$ to $\left.46^{\circ} \mathrm{C}\right)$ have not been reported. The enhanced expression of Ssa2p in the CGT1 mutant might well explain its increased resistance to heat stress, although the precise mechanism of action remains unclear.

In summary, lowering of CGT1 mRNA in C. albicans to below $50 \%$ of the normal level leads to an aberrant colony morphology, a slight increase in the lag phase of growth and a globally reduced level of protein expression, but the overall functionality of the pathogen and its ability to cause infection remain surprisingly intact. Its increased resistance to hygromycin B and heat stress might even allow it to cope under less favourable growth conditions. Therefore, it might not prove easy to develop a sufficiently effective drug for this molecular target. 


\section{ACKNOWLEDGEMENTS}

We sincerely thank Dr Britta Seideman (WITA, Germany) for advice on the two-dimensional gel electrophoresis work and subsequent analysis. We would also like to thank Dr William Fonzi (University of California, Irvine, USA) for supplying us with the CAI-4 strain and Dr Yamada-Okabe (Nippon Roche Research Center, Japan) for providing the C. albicans CGT1 cDNA clone. We thank Inge Loonen and Sandy Vandoninck (both at JRF) for technical support, Dr Peter Verhasselt (JRF) for sequence verification of the constructs and Gert Verheyen (JRF) for graphical support. We gratefully acknowledge Frans Van Gerven, Michel Oris and Pascal Van Dorsselaer (all at JRF) for virulence analysis of dCGT1. We thank Dr Jorge Vialard (JRF) for critical reading of the manuscript. This work was supported in part by the "Vlaams Instituut voor de Bevordering van het Wetenschappelijk-Technologisch Onderzoek in de Industrie' (IWT, Belgium, grant 960192).

\section{REFERENCES}

Blackstock, W. P. \& Weir, M. P. (1999). Proteomics: quantitative and physical mapping of cellular proteins. Trends Biotechnol 17, 121-127.

Brockstedt, E., Rickers, A., Kostka, S., Laubersheimer, A., Dorken, B., Wittmann-Liebold, B., Bommert, K. \& Otto, A. (1998). Identification of apoptosis-associated proteins in a human Burkitt lymphoma cell line: cleavage of heterogeneous nuclear ribonucleoprotein A1 by caspase 3. J Biol Chem 273, 28057-28064.

Buffo, J., Herman, M. A. \& Soll, D. R. (1984). A characterization of $\mathrm{pH}$-regulated dimorphism in Candida albicans. Mycopathologia 85, 21-30.

Dinman, J. D. \& Kinzy, T. G. (1997). Translational misreading: mutations in translation elongation factor $1 \alpha$ differentially affect programmed ribosomal frameshifting and drug sensitivity. RNA 3, 870-881.

Eckerskorn, C., Jungblut, P., Mewes, W., Klose, J. \& Lottspeich, L. (1988). Identification of mouse brain proteins after twodimensional electrophoresis and electroblotting by microsequence analysis and amino acid composition analysis. Electrophoresis 9, 830-838.

Ellis, R. J. \& van der Vies, S. M. (1991). Molecular chaperones. Ann Rev Biochem 60, 321-347.

Fonzi, W. A. \& Irwin, M. Y. (1993). Isogenic strain construction and gene mapping in Candida albicans. Genetics 134, 717-728.

Fresco, L. D. \& Buratowski, S. (1996). Conditional mutants of the yeast mRNA capping enzyme show that the cap enhances but is not required for mRNA splicing. RNA 2, 584-596.

Furuichi, Y. \& Miura, K. (1975). A blocked structure at the $5^{\prime}$ terminus of mRNA from cytoplasmic polyhedrosis virus. Nature 253, 374-375.

Furuichi, Y., Morgan, M., Muthukrishnan, S. \& Shatkin, A. J. (1975). Methylated, blocked $5^{\prime}$ termini in HeLa cell mRNA. Proc Natl Acad Sci USA 72, 362-366.

Gerring, S. L., Connelly, C. \& Hieter, P. (1991). Positional mapping of genes by chromosome blotting and chromosome fragmentation. Methods Enzymol 194, 57-77.

Giaever, G., Shoemaker, D. D., Jones, T. W., Liang, H., Winzeler, E. A., Astromoff, A. \& Davis, R. W. (1999). Genomic profiling of drug sensitivities via induced haploinsufficiency. Nature Genet 21, 278-283.

Gonzalez, A., Jiménez, A., Vazquez, D., Davies, J. E. \& Schindler, D. (1978). Studies on the mode of action of hygromycin B, an inhibitor of translocation in eukaryotes. Biochim Biophys Acta 521, 459-469.

Groll, A. H., Piscitelli, S. C. \& Walsh, T. J. (1998). Clinical pharmacology of systemic antifungal agents: a comprehensive review of agents in clinical use, current investigational compounds, and putative targets for antifungal drug development. Adv Pharmacol 44, 343-501.

Heid, C. A., Stevens, J., Livak, K. J. \& Williams, P. M. (1996). Real time quantitative PCR. Genome Methods 6, 986-994.

Henzel, W. J., Billeci, T. M., Stultz, J. T., Wong, S. C., Grimley, C. \& Wanatabe, C. (1993). Identifying proteins from two-dimensional gels by molecular mass searching of peptide fragments in protein sequence databases. Proc Natl Acad Sci USA 90, 5011-5015.

Heukeshoven, J. \& Dernick, R. (1985). Increased sensitivity for Coomassie staining of sodium dodecyl sulfate-polyacrylamide gels using PhastSyst Development Unit. Electrophoresis 6, 103-112.

Hinnebusch, A. G. \& Liebman, S. W. (1991). Translation elongation in yeast. In The Molecular Biology of the Yeast Saccharomyces. Edited by J. R. Broach, J. R. Pringle \& E. W. Jones. Cold Spring Harbor, NY : Cold Spring Harbor Laboratory. Ignatovich, O., Cooper, M., Kulesza, H. M. \& Beggs, J. D. (1995). Cloning and characterization of the gene encoding the ribosomal protein S5 of Saccharomyces cerevisiae. Nucleic Acids Res 23, 4616-4619.

Klose, J. \& Kobalz, U. (1995). Two-dimensional electrophoresis of proteins: an updated protocol and implications for a functional analysis of the genome. Electrophoresis 16, 1034-1059.

Kovalchuke, O., Kambampati, R., Pladies, E. \& Chakraburty, K. (1998). Competition and cooperation amongst yeast elongation factors. Eur J Biochem 258, 986-993.

Lay, J., Henry, L. K., Clifford, J., Koltin, Y., Bulawa, C. E. \& Becker, J. M. (1998). Altered expression of selectable marker URA3 in gene-disrupted Candida albicans strains complicates interpretation of virulence studies. Infect Immun 66, 5301-5306.

Lee, K. L., Buckley, H. R. \& Campbell, C. C. (1975). An amino acid liquid synthetic medium for the development of mycelial and yeast forms of Candida albicans. Sabouraudia 13, 148-153.

Lie, Y. S. \& Petropoulos, C. J. (1998). Advances in quantitative PCR technology: 5' nuclease assays. Curr Opin Biotechnol 9, 43-48.

Liu, J. \& Fallon, A. M. (1998). Effect of nutrient deprivation on ribosomal RNA and ribosomal protein mRNA in cultured mosquito cells. Arch Insect Biochem Physiol 37, 239-247.

Livak, K. J., Flood, S. J., Marmaro, J., Giusti, W. \& Deetz, K. (1995). Oligonucleotides with fluorescent dyes at opposite ends provide a quenched probe system useful for detecting PCR product and nucleic acid hybridization. Genome Res 4, 357-362.

Lopez-Ribot, J. L., Alloush, H. M., Masten, B. J. \& Chaffin, W. L. (1996). Evidence for presence in the cell wall of Candida albicans of a protein related to the hsp70 family. Infect Immun 64, 3333-3340.

Magee, B. B. (1994a). Preparation and digestion of chromosomesized DNA. In Molecular Biology of Pathogenic Fungi, a Laboratory Manual, pp. 85-89. Edited by B. Maresca \& G. Kobayashi. New York: Telos Press.

Magee, B. B. (1994b). Chromosome separation by pulsed-field gel electrophoresis. In Molecular Biology of Pathogenic Fungi, a Laboratory Manual, pp. 95-98. Edited by B. Maresca \& G. Kobayashi. New York: Telos Press.

Mager, W. H. \& Ferreira, P. M. (1993). Stress response of yeast. Biochem J. 290, 1-13. 
Mao, X., Schwer, B. \& Shuman, S. (1995). Yeast mRNA cap methyltransferase is a 50-kilodalton protein encoded by an essential gene. Mol Cell Biol 15, 4167-4174.

Morrow, B., Anderson, J., Wilson, J. \& Soll, D. R. (1989). Bidirectional stimulation of the white-opaque transition of Candida albicans by ultraviolet irradiation. J Gen Microbiol 135, 1201-1208.

Mueller, E., Schuemann, M., Rickers, A., Bommert, K., WittmannLiebold, B. \& Otto, A. (1999). Study of Burkitt lymphoma cell line proteins by high resolution two-dimensional gel electrophoresis and nanoelectrospray mass spectrometry. Electrophoresis 20, 320-330.

Nicolet, C. M. \& Craig, E. A. (1991). Functional analysis of a conserved amino-terminal region of HSP70 by site-directed mutagenesis. Yeast 7, 699-716.

Odds, F. C. (1991). Quantitative microculture system with standardized inocula for strain typing, susceptibility testing, and other physiologic measurements with Candida albicans and other yeasts. J Clin Microbiol 29, 2735-2740.

Orlando, C., Pinzani, P. \& Pazzagli, M. (1998). Developments in quantitative PCR. Clin Chem Lab Med 36, 255-269.

Otto, A., Thiede, B., Muller, E. Ch., Scheler, C., Wittmann-Liebold, B. \& Jungblut, P. (1996). Identification of human myocardial proteins separated by two-dimensional electrophoresis using an effective sample preparation for mass spectrometry. Electrophoresis 17, 1643-1650.

Palmer, E., Wilhelm, J. M. \& Sherman, F. (1979). Phenotypic suppression of nonsense mutants in yeast by aminoglycoside antibiotics. Nature 277, 148-150.

Pérez-Martin, J., Uria, J. A. \& Johnson, A. D. (1999). Phenotypic switching in Candida albicans by a SIR2 gene. EMBO J 18, 2580-2592.

Ping Wang, S., Deng, L., Ho, C. K. \& Shuman, S. (1997). Phylogeny of mRNA capping enzymes. Proc Natl Acad Sci 94, 9573-9578.

Radford, D. L., Challacombe, S. J. \& Walter, J. D. (1994). A scanning electron miscroscopy investigation of the structure of colonies of different morphologies produced by phenotypic switching of Candida albicans. J Med Microbiol 40, 416-423.

Rikkerink, E. H., Magee, B. B. \& Magee, P. T. (1988). Opaquewhite phenotype transition: a programmed morphological transition in Candida albicans. J Bacteriol 170, 895-899.

Rustchenko-Bulgac, E. P., Sherman, F. \& Hicks, J. B. (1990). Chromosomal rearrangements associated with morphological mutants provide a means for genetic variation of Candida albicans. J Bacteriol 172, 1276-1283.

Sambrook, J., Fritsch, E. F. \& Maniatis, T. (1989). Molecular Cloning: a Laboratory Manual, 2nd edn. Cold Spring Harbor, NY: Cold Spring Harbor Laboratory.

Sandbaken, M. G., Lupisella, J. A., DiDomenico, B. \& Chakraburtty, K. (1990). Protein synthesis in yeast: structural and functional analysis of the gene encoding elongation factor $3 . J$ Biol Chem 265, 15838-15844.

Schwer, B. \& Shuman, S. (1994). Mutational analysis of yeast mRNA capping enzyme. Proc Natl Acad Sci USA 91, 4328-4332.

Schwer, B. \& Shuman, S. (1996). Conditional inactivation of mRNA capping enzyme affects yeast pre-mRNA splicing in vivo. RNA 2, 574-583.

Schwer, B., Mao, X. \& Shuman, S. (1998). Accelerated mRNA decay in conditional mutants of yeast mRNA capping enzyme. Nucleic Acids Res 26, 2050-2057.

Shibagaki, Y., Itoh, N., Yamada, H., Nagata, S. \& Mizumoto, K. (1992). mRNA capping enzyme: isolation and characterization of the gene encoding mRNA guanylyltransferase subunit from Saccharomyces cerevisiae. J Biol Chem 267, 9521-9528.

Shuman, S., Liu, Y. \& Schwer, B. (1994). Covalent catalysis in nucleotidyl transfer reactions: essential motifs in Saccharomyces cerevisiae RNA capping enzyme are conserved in Schizosaccharomyces pombe and viral capping enzymes and among polynucleotide ligases. Proc Natl Acad Sci USA 91, 12046-12050.

Simonin, D., Diaz, J. J., Masse, T. \& Madjar, J. J. (1997). Persistence of ribosomal protein synthesis after infection of HeLa cells by herpes simplex virus type I. J Gen Virol 78, 435-443.

Singh, A., Ursic, D. \& Davies, J. (1979). Phenotypic suppression and misreading in Saccharomyces cerevisiae. Nature 277, 146-148.

Slutsky, B., Buffo, J. \& Soll, D. R. (1985). High-frequency switching of colony morphology in Candida albicans. Science 230, 666-669.

Smith, D. B. \& Johnson, K. S. (1988). Single-step purification of polypeptides expressed in Escherichia coli as fusions with glutathione S-transferase. Gene 67, 31-40.

Soll, D. R. (1986). The regulation of cellular differentiation in the dimorphic yeast Candida albicans. Bioessays 5, 5-11.

Soll, D. R. (1992). High-frequency switching in Candida albicans. Clin Microbiol Rev 5, 183-203.

Sundstrom, P., Smith, D. \& Sypherd, P. S. (1990). Sequence analysis and expression of the two genes for elongation factor $1 \alpha$ from the dimorphic yeast Candida albicans. J Bacteriol 172, 2036-2045.

Wei, C. M. \& Moss, B. (1975). Methylated nucleotides block 5'terminus of vaccinia virus messenger RNA. Proc Natl Acad Sci USA 72, 318-322.

Wittman-Liebold, B. (1992). High sensitive protein sequence analysis. Pure Appl Chem 64, 537-543.

Woolford, J. L. \& Warner, J. R. (1991). The ribosome and its synthesis. In The Molecular and Cellular Biology of the Yeast Saccharomyces cerevisiae, vol. 1, pp. 587-626. Edited by J. R. Broach, J. R. Pringle \& E. W. Jones. Cold Spring Harbor, NY: Cold Spring Harbor Laboratory.

Yamada-Okabe, T., Shimmi, O., Doi, R., Mizumoto, K., Arisawa, M. \& Yamada-Okabe, H. (1996). Isolation of the mRNA-capping enzyme and ferric-reductase-related genes from Candida albicans. Microbiology 142, 2515-2523.

Yamada-Okabe, T., Mio, T., Matsui, M., Kashuma, Y., Arisawa, M. \& Yamada-Okabe, H. (1998a). Isolation and characterization of the Candida albicans gene for mRNA 5'-triphosphatase: association of mRNA $5^{\prime}$-triphosphatase and mRNA $5^{\prime}$ guanylyltransferase activities is essential for the function of mRNA 5'-capping enzyme in vivo. FEBS Lett 435, 49-54.

Yamada-Okabe, T., Doi, R., Shimmi, O., Arisawa, M. \& YamadaOkabe, H. (1998b). Isolation and characterization of a human cDNA for mRNA 5'-capping enzyme. Nucleic Acids Res 26, 1700-1706.

Zeuthen, M. L. \& Howard, D. H. (1989). Thermotolerance and the heat-shock response in Candida albicans. J Gen Microbiol 135, 2509-2518.

Received 23 August 1999; revised 23 September 1999; accepted 3 November 1999. 